\title{
Effect of Tunicamycin on Biosynthesis, Processing and Release of Proopiomelanocortin-Derived Peptides in the Intermediate Lobe of the Frog Rana ridibunda
}

\author{
HUBERT VAUDRY, BRUCE G. JENKS, ${ }^{*}$ LIDY VERBURG-VAN KEMENADE* \\ AND MARIE-CHRISTINE TONON \\ Groupe de Recherche en Endocrinologie Moléculaire, UA CNRS 650, Unité Alliée à l'INSERM \\ Faculté des Sciences, Université de Rouen, 76130 Mont-Saint-Aignan, France \\ *Department of Zoology II, Faculty of Sciences, Catholic University \\ Toernooiveld, 6525 ED Nijmegen, The Netherlands
}

Received 4 September 1985

\begin{abstract}
VAUDRY, H., B. G. JENKS, L. VERBURG-VAN KEMENADE AND M.-C. TONON. Effect of tunicamycin on biosynthesis, processing and release of proopiomelanocortin-derived peptides in the intermediate lobe of the frog Rana ridibunda. PEPTIDES 7(2) 163-169, 1986.-The intermediate lobe of the pituitary gland synthesizes a glycoprotein, proopiomelanocortin (POMC), which is cleaved by specific proteolytic enzymes to generate several hormonal peptides. The purpose of the present study was to examine the possible role of the carbohydrate moiety in the synthesis, intracellular processing and release of POMC-derived peptides in frog (Rana ridibunda) intermediate lobe cells. In vitro incorporation of $\left[{ }^{3} \mathrm{H}\right]$-labelled glucosamine gave rise to three major radioactive products. Trypsin digestion of each of these glycopeptides gave a single glucosamine-labelled tryptic fragment with identical chromatographic characteristics. We conclude that $R a n a$ POMC is glycosylated in only one site (its $\gamma$-MSH region) and that intracellular processing of this prohormone gives rise to smaller glycopeptides including glycosylated $\gamma$-MSH. Treatment with the antibiotic tunicamycin $(10 \mu \mathrm{g} / \mathrm{ml}, 6 \mathrm{hr})$ inhibited the glycosylation of POMC but did not significantly alter the neosynthesis of the peptide moiety of the precursor. Pulsechase experiments combined with high-performance liquid chromatography analysis of the peptides derived from POMC revealed that inhibition of glycosylation by tunicamycin had no effect on the enzymatic cleavage of the precursor nor on the release of mature peptides. Thus, it is concluded that, in the frog, glycosylation of POMC has no influence on the biosynthesis, processing and release of intermediate lobe hormones.
\end{abstract}

Proopiomelanocortin Gamma-melanotropin Glycosylation Tunicamycin Processing Secretion

MANY proteinous secretory products of cells, or the precursor proteins of these products, have proved to be glycosylated. The carbohydrate moiety on hormones such as human chorionic gonadotropin may play an important role in hormonal activity at the level of the target tissue $[22,41]$. The functional significance of glycosylation is less clear in the case where the biologically active secretory peptide is nonglycosylated but has a glycosylated precursor protein, as in the case for the peptide hormones vasopressin $[10,35,39]$ and calcitonin [17] and their respective prohormones. Possibly the carbohydrate on these precursors could have an intracellular function such as direction of intracellular transport or cleavage of the precursor or act as a signal during sorting of peptides for intracellular degradation or secretion. Indeed, there is evidence that glycosylation may have a function in packaging and transport of secretory material in the hypothalamo-neurohypophyseal system of the rat [11]. In studies concerning the functional significance of glycosylation, the precursor protein proopiomelanocortin (POMC) is interesting because: (1) in most species this is a glycosylated prohormone, (2) processing (cleavage) of this precursor is tissue-specific which leads to a different spectrum of peptides in different POMC-producing cell populations, and (3) some of the secretory products derived from this prohormone are glycopeptides of potential biological importance.

A valuable tool in the study of the functional significance of glycosylation has been the use of the antibiotic tunicamycin, which blocks asparagine-linked $\mathrm{N}$-glycosylation of proteins $[15,40]$. Loh and Gainer [27-29] were the first to apply this antibiotic to studies concerning POMC-producing cells. They reported that in the pars intermedia of the pitui- 
tary gland of the amphibian, Xenopus laevis, nonglycosylated POMC undergoes random proteolysis from which they concluded that the carbohydrate group of the prohormone may be involved in determining the direction of the processing. In a subsequent study [30] they suggested that the rapid proteolysis of the non-glycosylated prohormone might in fact reflect misrouting of proteolytic enzymes in the tunicamycin-treated tissue. In similar studies with a mouse corticotropin-producing tumor cell line [4] and with the pars intermedia of the mouse $[19,21]$ it has been concluded that processing of POMC is not grossly altered when its glycosylation is prevented.

In the amphibian pars intermedia melanotropic peptides are among the terminal products of the processing of POMC. These peptides are released in animals placed on a black background and thus the pars intermedia has an important function in regulating skin color $[12,13]$. We have previously conducted biosynthetic studies with the pars intermedia of the frog, Rana ridibunda $[20,44,45]$. These studies revealed that POMC of the frog intermediate lobe is a glycoprotein and that glycopeptides are among the secretory products of this tissue. The present study further characterizes these glycosylated products and examines the effects of tunicamicyn treatment on biosynthesis and release of peptides from the frog pars intermedia.

\section{METHOD}

\section{Animals}

Adult male frogs (Rana ridibunda) of about $40 \mathrm{~g}$ body weight were obtained from a commercial source (Couétard, St. Hilaire-de-Riez, France). Since dark-background adaptation enhances the biosynthetic activity of the intermediate lobe cells, the animals were placed in black tanks under constant illumination for 4 days.

\section{SDS-Electrophoretic Analysis of Newly Synthesized POMC/18K-Fragment}

Preliminary experiments were conducted to determine the treatment time with tunicamycin which gave optimum inhibition of glycosylation of POMC. Neurointermediate lobes were incubated for up to $8 \mathrm{hr}$ in medium containing 10 $\mu \mathrm{g} / \mathrm{ml}$ tunicamycin (Sigma) at $22^{\circ} \mathrm{C}$. Composition of the incubation medium was: $\mathrm{NaCl}, 112 \mathrm{mM} ; \mathrm{CaCl}_{2}, 2 \mathrm{mM} ; \mathrm{KCl}, 2$ $\mathrm{mM}$; Hepes (ultrograde, Calbiochem), $15 \mathrm{mM}$; glucose, 2 $\mathrm{mg} / \mathrm{ml}$; bovine serum albumin (BSA, fraction V, Sigma), 0.3 $\mathrm{mg} / \mathrm{ml}$. Before use the medium was gassed for $15 \mathrm{~min}$ with $\mathrm{O}_{2}-\mathrm{CO}_{2}(95-5)$ and the $\mathrm{pH}$ adjusted to 7.35. Following the preincubation in tunicamycin the lobes were pulse incubated for $4 \mathrm{hr}$ in $40 \mu \mathrm{l}$ medium containing $40 \mu \mathrm{Ci}\left[{ }^{3} \mathrm{H}\right] l y$ sine (76 $\mathrm{Ci} /$ mmole, Amersham) and $40 \mu \mathrm{Ci}\left[{ }^{3} \mathrm{H}\right]$ proline (31 $\mathrm{Ci} / \mathrm{mmole}$, Amersham). Tunicamycin was also present during the pulse incubation. Control lobes were given identical incubation paradigms except tunicamycin was omitted from the incubation medium. Following the pulse incubation the lobes were homogenized in $500 \mu \mathrm{l} 0.1 \mathrm{~N} \mathrm{HCl}$ and the extracts submitted to SDS-gel electrophoresis as described earlier [45]. The effectiveness of tunicamycin treatment in inhibiting glycosylation could be monitored on autoradiograms of the SDS-gels by observing the relative amount of newly synthesized POMC-related peptides in the higher molecular weight glycosylated-form and the lower molecular weight nonglycosylated-form. The results of the preliminary experiments indicated that a $6-\mathrm{hr}$ preincubation in tunicamycin gave maximum inhibition of glycosylation and this preincubation time was therefore selected in an experiment to quantify the effects of the antibiotic. In this experiment the incubation conditions were exactly the same as those described above and 5 individual neurointermediate lobes were treated with tunicamycin and 5 individual lobes functioned as controls. Quantification of the relative levels of glycosylated and non-glycosylated proteins on the electrophoretogram was conducted by scanning densitometry (Biorad scanning densitometer model 1650) of flurograms prepared according to the method of Bonner and Laskey [3].

\section{HPLC Analysis of Incorporation of $\left[{ }^{3} H\right]$ Glucosamine}

Six neurointermediate lobes were preincubated for $6 \mathrm{hr}$ in $1 \mathrm{ml}$ medium in the absence (control, $\mathrm{n}=3$ ) or in the presence $(\mathrm{n}=3)$ of tunicamycin $(10 \mu \mathrm{g} / \mathrm{ml})$. Each group was then incubated for $8 \mathrm{hr}$ in $40 \mu \mathrm{l}$ medium containing $100 \mu \mathrm{Ci}$ $\left[{ }^{3} \mathrm{H}\right]$ glucosamine $(40 \mathrm{Ci} / \mathrm{mmol}$, Amersham $)$. Previous pulse-chase experiments [45] have shown that $8 \mathrm{hr}$ is sufficient time for processing of POMC to terminal products and, therefore, that the tissue following $8 \mathrm{hr}$ of continuous labelling should contain both terminal products and all biosynthetic intermediates of POMC-processing. The composition of the incubation medium was identical to that described above except glucose was omitted. Each lobe was then extracted in $500 \mu \mathrm{l} 0.1 \mathrm{~N} \mathrm{HCl}$ and the extract stored frozen until analyzed by high performance liquid chromatography.

Glucose was omitted from the incubation medium in the above exreriment in the expectation that it might retard incorporation of $\left[{ }^{3} \mathrm{H}\right]$ glucosamine. An additional experiment was conducted where glucose was present $(2 \mathrm{mg} / \mathrm{ml})$ during all incubation.

Reverse phase HPLC was performed on a Spectra Physics (model SP 8000) liquid chromatograph equipped with a $4.6 \times 240 \mathrm{~mm}$ Spherisorb 10 ODS column (Chrompack) as reported in [45]. The mobile phase consisted of a gradient established with $0.5 \mathrm{M}$ formic acid/0.1 M pyridine (primary solvent) and 1-propanol (secondary solvent); the gradient used is presented in Fig. 1. The column was eluted at a flow rate of $2.0 \mathrm{ml} / \mathrm{min}$. Fractions were collected every $0.5 \mathrm{~min}$ $(1.0 \mathrm{ml})$ and $4 \mathrm{ml}$ of scintillation fluid (Scintillator 299, Packard) was added. All fractions were counted on a liquid scintillation analyser for 2 min (LKB Rackbeta).

\section{Tryptic Mapping of $\left[{ }^{3} \mathrm{H}\right]$ Glucosamine Labelled Peptides}

Five neurointermediate lobes were incubated in $40 \mu \mathrm{l}$ medium containing $100 \mu \mathrm{Ci}\left[{ }^{3} \mathrm{H}\right]$ glucosamine. Labelled peptides were resolved by HPLC and three radioactive peaks corresponding to glycosylated peptides were isolated. These samples were dried, redisolved in $200 \mu 115 \mathrm{mM}$ Hepes buffer (pH 8) and incubated at $37^{\circ} \mathrm{C}$ with $20 \mu \mathrm{g}$ trypsin (DPCC treated, Sigma). Digestion of compounds designated I and V (see the Results section) was conducted for $2^{1 / 2} \mathrm{hr}$ in the presence of $20 \mu \mathrm{g}$ BSA whereas digestion of peak XI was conducted for $24 \mathrm{hr}$ in the absence of BSA. Longer digestion time was used with peak XI as it represents large proteins which require more rigorous digestion conditions. Digestion was terminated by adding $500 \mu 10.1 \mathrm{~N} \mathrm{HCl}$ and the radioactive peptide fragments were analysed by HPLC using the same mobile phase as described above. The gradient used for elution of the tryptic fragments is presented in Fig. 2. This gradient is less steep that the previous gradient to allow better resolution of small peptide fragments expected from the 

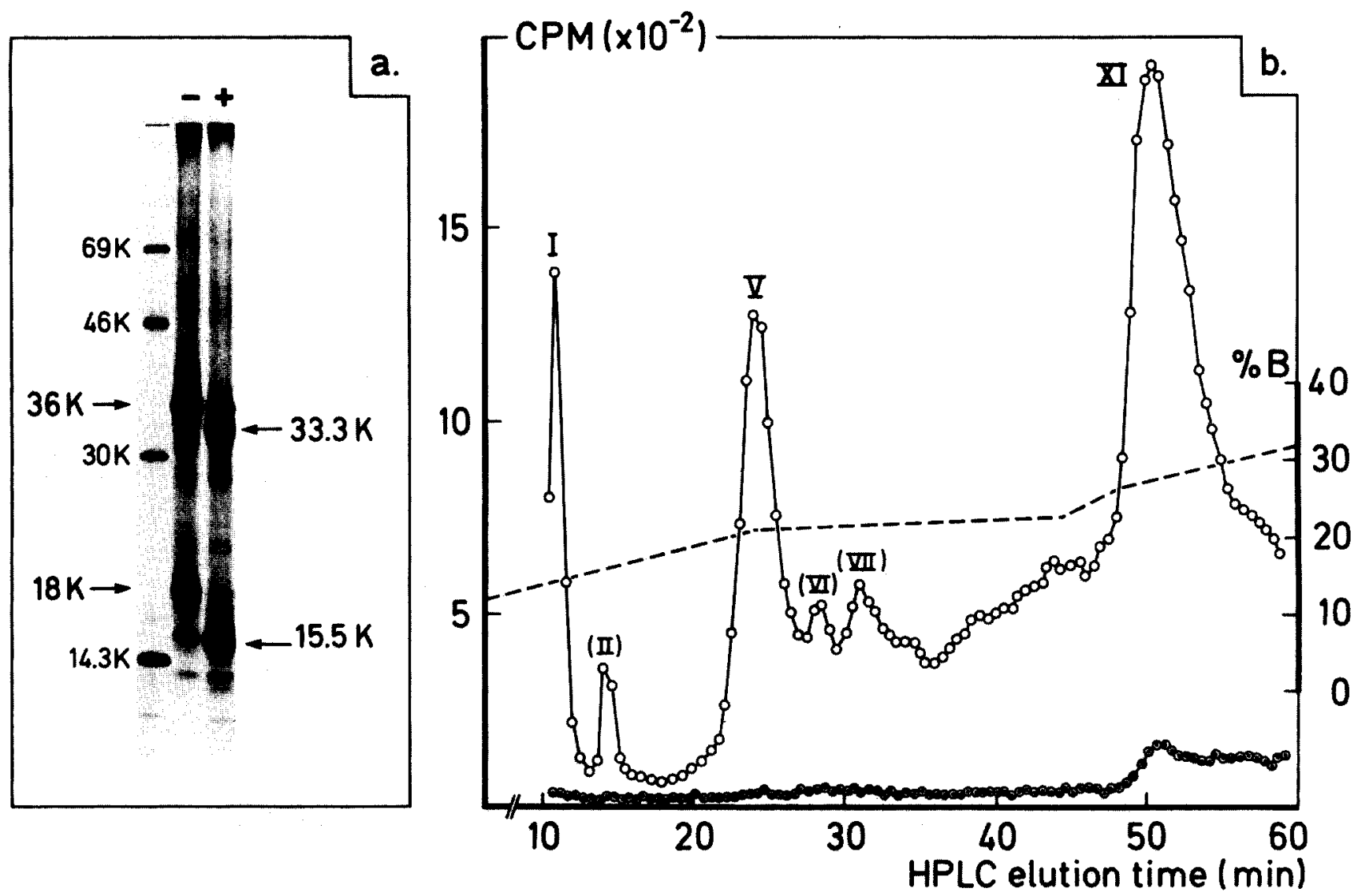

FIG. 1. (a): SDS-gel electrophoretic analysis of the effect of tunicamycin on protein biosynthesis in neurointermediate lobes of the frog. Lobes were preincubated for $6 \mathrm{hr}$ in the absence (control, - ) or presence of tunicamycin $(+)$ and then incubated $4 \mathrm{hr}$ in medium containing $\left[{ }^{3} \mathrm{H}\right]$ lysine and $\left[{ }^{3} \mathrm{H}\right]$ proline. Molecular weights of the radioactive proteins are calculated relative to the radioactive markers on the SDS-gel. ( $\mathrm{K}=$ kilodalton). (b): HPLC analysis of $\left[{ }^{3} \mathrm{H}\right]$ glucosamine labelled peptides synthesized by frog neurointermediate lobes in the absence $(\mathrm{O})$ or presence $(\odot)$ of tunicamycin. Lobes were preincubated for $6 \mathrm{hr}$ and then incubated for $8 \mathrm{hr}$ in medium containing $\left[{ }^{3} \mathrm{H}\right] \mathrm{glucosamine}$. HPLC elution gradient is given (\% secondary solvent, B). Identification of products has been reported [45]. Peak I corresponds to $\gamma$-MSH; peak V to $\gamma$-MSH intermediate; peak XI contains both POMC and 18K-fragment.

trypsin digestion. It has been applied previously in characterization of POMC-related peptides $[18,19,33,34,44,45]$.

\section{Pulse-Chase Analysis of Processing and Release of POMC-Related Peptides}

Ten neurointermediate lobes were preincubated for $6 \mathrm{hr}$ at $22^{\circ} \mathrm{C}$ in $1 \mathrm{ml}$ medium in the absence (control; $n=5$ ) or in the presence $(n=5)$ of tunicamycin. Then, the lobes were pulse-incubated for $4 \mathrm{hr}$ in $40 \mu \mathrm{l}$ medium containing $\left[{ }^{3} \mathrm{H}\right]$ tyrosine $(46 \mathrm{Ci} / \mathrm{mmole}),\left[{ }^{3} \mathrm{H}\right]$ phenylalanine $(120 \mathrm{Ci} /$ mmole), $\left[{ }^{3} \mathrm{H}\right]$ lysine $(90 \mathrm{Ci} / \mathrm{mmole})$ and $\left[{ }^{3} \mathrm{H}\right]$ proline $(115 \mathrm{Ci} /$ mmole) (Amersham, $40 \mu \mathrm{Ci}$ each) in the absence or in the presence of tunicamycin, respectively. At the end of the pulse incubation, the lobes were rinsed with medium containing $2 \mathrm{mM}$ of the homologous non-labelled amino acids (chase-medium) and they were then incubated separately in $500 \mu \mathrm{l}$ of chase-medium for $10 \mathrm{hr}$. Tunicamycin was present during the pulse-incubation of the tunicamycin-treated lobes but was omitted from all chase incubations. At the end of the incubations the chase-media were collected and acidified with $50 \mu 11 \mathrm{~N} \mathrm{HCl}$. Each lobe was extracted in $500 \mu 10.1 \mathrm{~N}$ $\mathrm{HCl}$. Both tissue extracts and media were submitted to HPLC.
In separate experiment $\left[{ }^{3} \mathrm{H}\right]$ lysine labelled peptides synthesized by control and tunicamycin-treated tissue were isolated by HPLC and samples of one of the isolated peptides (peak I, see the Results section) was resubmitted to HPLC using shallower elution gradients than used in the experiment outlined above. For preparation of these peptides, pretreatment with tunicamycin was for $6 \mathrm{hr}$ and the lobes were then incubated for $6 \mathrm{hr}$ in $40 \mu \mathrm{l}$ medium containing $100 \mu \mathrm{Ci}$ $\left[{ }^{3} \mathrm{H}\right]$ lysine. In the case of the tunicamycin group, antibiotic treatment was continued during this latter incubation.

\section{RESULTS}

Effects of Tunicamycin on Biosynthesis of POMC/I8KFragment

The frog neurointermediate lobe synthesizes a $36 \mathrm{~K}$ and an $18 \mathrm{~K}$ protein (Fig. 1a, left lane). A previous study [45] has shown that the $36 \mathrm{~K}$ protein is immunoprecipitable with antisera to both $\gamma$-MSH and $\beta$-endorphin and that it is rapidly synthesized during pulse-incubations and dissappears during chase-incubations. Therefore it was designated the prohormone, POMC. The $18 \mathrm{~K}$ protein is immunoprecipitable with antiserum to $\gamma$-MSH and it was thus concluded that it likely represents the $\mathrm{NH}_{2}$-terminal fragment of POMC. It 

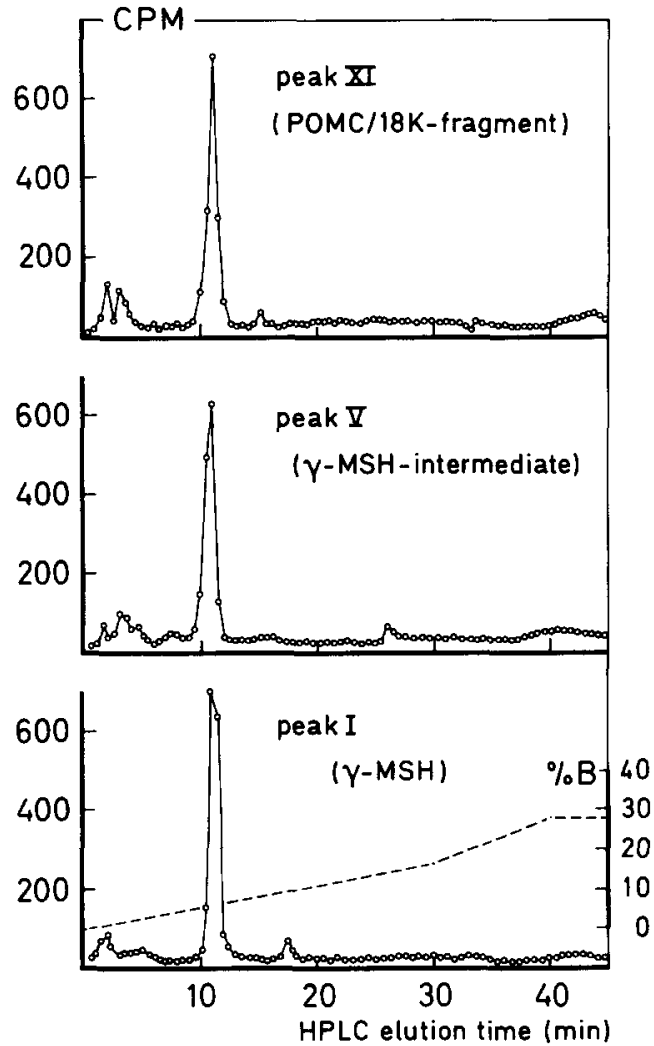

FIG. 2. HPLC analysis of radioactive tryptic fragments generated from trypsin digestion of $\left[{ }^{3} \mathrm{H}\right]$ glucosamine-labelled products of the frog pars intermedia. Neurointermediate lobes were incubated in [ $\left.{ }^{3} \mathrm{H}\right]$ glucosamine, the glucosamine-labelled peptides were isolated by HPLC (see Fig. 1b) and samples of these peptides were then submitted to trypsin digestion and the digestate analyzed by HPLC using the gradient shown (\% secondary solvent, B).

was designated the $18 \mathrm{~K}$-fragment in analogy with the $16 \mathrm{~K}$ fragment of mammalian POMC-peptide terminology. In tunicamycin-treated lobes there was a dramatic reduction in the amount of both the $36 \mathrm{~K}$ POMC and $18 \mathrm{~K}$-fragment synthesized (Fig. 1a, right lane). In this latter tissue two new radioactive products are found, with molecular weights of 33.3K and 15.5K. Presumably they represent nonglycosylated forms of POMC and $18 \mathrm{~K}$-fragment respectively. The preliminary experiments indicated that inhibition of glycosylation, exemplified by the lack of $36 \mathrm{~K} \mathrm{POMC}$ and $18 \mathrm{~K}$-fragment, had reached a maximum with a $6 \mathrm{hr}$ preincubation in tunicamycin and consequently this duration of treatment was used in all subsequent experiments. Densitometry of fluorograms showed that $6 \mathrm{hr}$ pre-treatment gave $82.1 \pm 6.5 \% \quad(n=5)$ inhibition of glycosylation of POMC/18K-fragment with very little effect on the level of radioactive amino acid incorporation into these proteins (tunicamycin group $105.2 \pm 14.0 \%(n=5)$ of control group).

\section{Characterization of Glycosylated Peptides}

Previous studies [45] have shown that HPLC analysis resolves a number of newly synthesized peptides in the neurointermediate lobe of Rana; these were numbered I-XI according to their elution position from the column. Analysis of lobe extracts following tissue incubation in the presence of $\left[{ }^{3} \mathrm{H}\right]$ glucosamine shows the presence of sugar in peaks $\mathrm{I}, \mathrm{V}$ and XI (Fig. 1b). Peak XI represents co-eluting proteins $36 \mathrm{~K}$ POMC and 18K-fragment [45]. Immunoprecipitation experiments and pulse-chase analysis of biosynthesis have shown peak I and V to represent peptides related to $\gamma$-MSH; peak V was designated $\gamma$-MSH-intermediate and peak I designated $\gamma$-MSH [46]. In the presence of tunicamycin there is clearly an inhibition of the incorporation of $\left[{ }^{3} \mathrm{H}\right]$ glucosamine into the glycosylated peptides and proteins (Fig. 1b). The low level of incorporation of radioactivity into products with elution times corresponding to non-glycosylated peptides of POMC processing (e.g., peaks II, VI and VII, see following section) is not understood. The HPLC profiles obtained in the experiments where glucose was omitted from the incubation medium (Fig. 1b) were essentially the same as those obtained in experiments conducted with glucose in the medium (data not shown). Thus, the possibility that this low level of incorporation reflects utilization of glucosamine in metabolic pathways leading to the production of amino acids, ultimately expressed in POMC-related peptides, seems unlikely.

The HPLC analysis of the trypsin digestate of $\left[{ }^{3} \mathrm{H}\right]$ glucosamine labelled $\gamma$-MSH, $\gamma$-MSH-intermediate and 36K POMC/18K-fragment is shown in Fig. 2. This analysis indicates that, in each case, a single radioactive fragment was generated through trypsin digestion. The tryptic fragments generated from these various peptides had an identical HPLC elution time.

\section{Effects of Tunicamycin on Processing and Release of POMC-Related Peptides}

Pulse-chase analysis of the incorporation of $\left[{ }^{3} \mathrm{H}\right]$ amino acids shows synthesis of a number of radioactive peptides (Fig. 3a, upper profile). Besides the glycosylated peptides already mentioned, the HPLC analysis also shows production of des-N $\alpha$-acetyl $\alpha$-MSH (product II), an endorphinlike-peptide (product VI) and corticotropin-like intermediate lobe peptide, CLIP (product VII); these peptides were characterized extensively in our previous study [45]. The lobes of the tunicamycin-treated group gave rise to newly synthesized products with HPLC retention times identical to those of the control group with one notable exception, product $\mathrm{V}$ (Fig. 3a, lower profile). Separate analysis of product I isolated from normal and tunicamycin-treated tissue revealed that the product synthesized by the latter tissue had a longer HPLC elution time when a shallower elution gradient was used (Fig. 3b).

Following the chase incubation, newly-synthesized peptides were found to be present in the incubation medium (Fig. 3c). Each product in the medium of the tunicamycin treated tissue (Fig. 3c, lower profile) corresponds exactly with a product found in the HPLC profile of the control medium (Fig. 3c, upper profile), with again the exception of product $\mathrm{V}$. Products III and IV represent $\mathrm{NH}_{2}$-terminal acetylated forms of des-N $\alpha$-acetyl $\alpha$-MSH $([20,44]$, see also the Discussion section). Product $A$, which we find only occassionally to be a biosynthetic product of frog intermediate lobes, remains to be identified [20].

\section{DISCUSSION}

The pars intermedia of the green frog, Rana ridibunda, synthesizes a $36 \mathrm{~K}$ glycosylated protein which we have previously designated as the prohormone, POMC [45]. Proteolytic processing of this prohormone has been shown to 

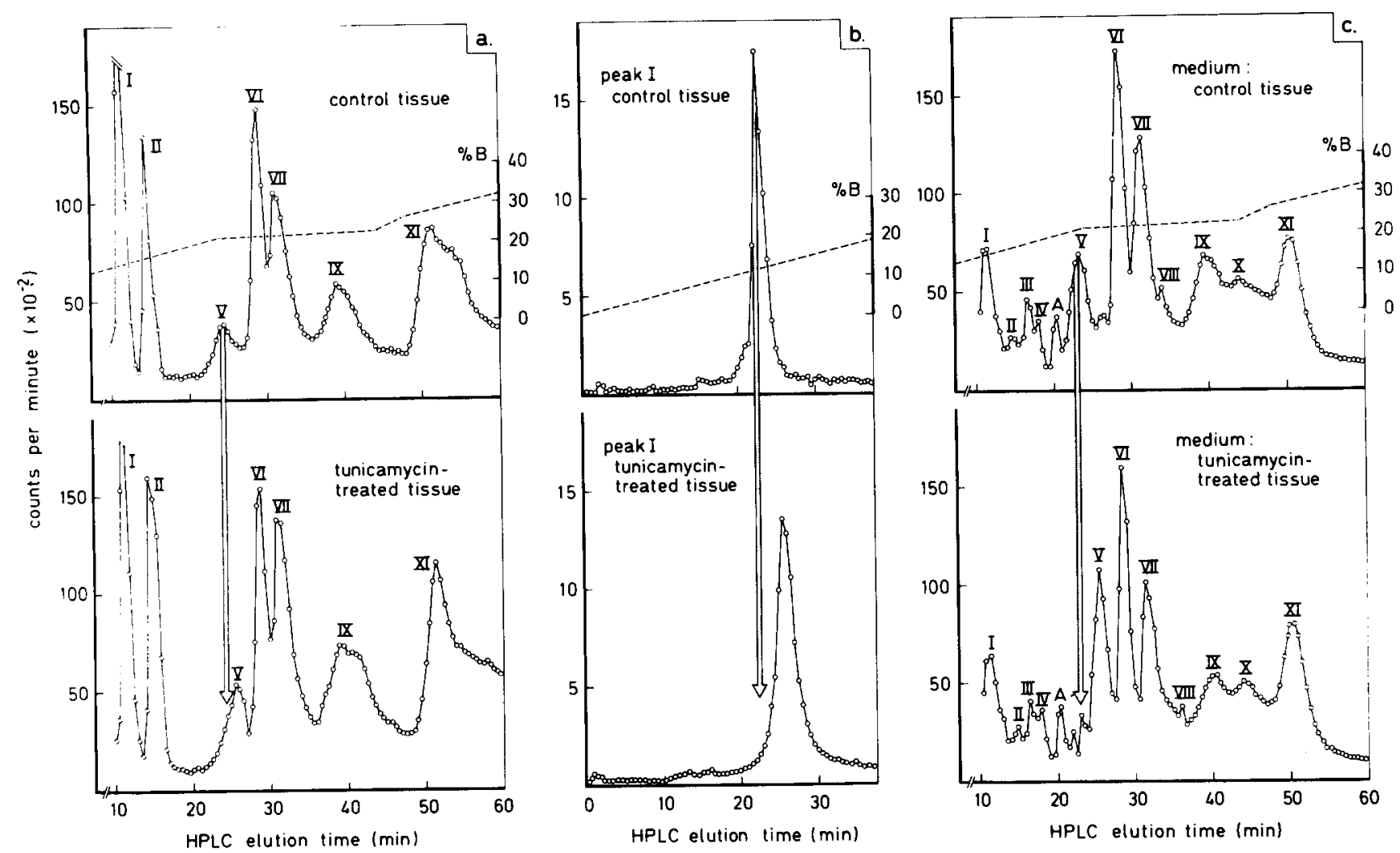

FIG. 3. (a): HPLC analysis of newly-synthesized peptides extracted from frog neurointermediate lobes of control (upper profile) and tunicamycin-treated tissue (lower profile). Lobes were preincubated for $6 \mathrm{hr}$, followed by a $\mathbf{4 h r}$ incubation in medium containing a mixture of radioactive amino acids and subsequently were chase-incubated for $10 \mathrm{hr}$. HPLC elution gradient is given (\% secondary solvent, B). Identification of products has been reported previously [45]: I, $\gamma$-MSH; II, des-N $\alpha$-acetyl $\alpha$-MSH; V, $\gamma$-MSH-intermediate; VI, endorphinlike-peptide; VII, CLIP; VII-X, unidentified; XI, coelution of POMC/18K-fragment. (b): Analysis of elution position of radiolabelled product $\mathrm{I}(\gamma$-MSH) synthesized by normal and tunicamycin-treated neurointermediate lobes using a shallower HPLC elution gradient than that given in (a). Radiolabelling was conducted with $\left[{ }^{3} \mathrm{H}\right]$ lysine and $\gamma$-MSH was isolated from lobe extracts. (c): HPLC analysis of newly synthesized peptides released to the chase-incubation medium of the experiment described in Fig. 1a. Products III and IV, whose presence is restricted to the incubation medium, have been identified as the monoacetylated and diacetylated form of $\alpha$-MSH respectively [20]. The identity of product $A$ is unknown.

generate several glycosylated peptides. On the basis of pulse-chase analysis of biosynthetic events in the pars intermedia of Rana, in combination with the results presented in the present investigation, we conclude that the biosynthetic sequence to produce $\gamma$-MSH involves cleavage of the prohormone to produce the $\mathrm{NH}_{2}$-terminal $18 \mathrm{~K}$-fragment of the POMC which is subsequently cleaved to generate first an intermediate peptide (designated $\gamma$-MSH-intermediate) and finally authentic $\gamma$-MSH. The fact that tunicamycin was effective in blocking the incorporation of $\left[{ }^{3} \mathrm{H}\right]$ glucosamine into these glycoproteins and glycopeptides indicates that their glycosylation is limited to the tunicamycin-sensitive asparagine-linked type. In that tryptic digestion of the glucosamine labelled products generated, in each case, only a single glucosamine labelled tryptic fragment, we further conclude that each peptide contains only a single oligosaccharide side-chain. As expected, each of the tryptic fragments generated from the various glycosylated products had identical HPLC elution times indicating that the glycosylation site within each of the peptides is identical. Altogether we conclude that frog POMC possesses a single glycosylation which is within the $\gamma$-MSH region of the prohormone.

There appears to be considerable species differences both in the number of oligosaccharide side-chains attached to
POMC and in the position of their attachment within the precursor molecule. POMC of another amphibian species, Xenopus laevis, has been shown to have a single glycosylation which is in the $\gamma$-MSH region [33,34], identical to the situation we now report for the frog prohormone. Characterization of POMC-related peptides of the salmon [23] and dogfish pituitary gland [32] suggests that the prohormones of these species are not glycosylated. The lack of binding to concanavalin of POMC isolated from the pituitary gland of Prochilodus platensis has led Iturriza and Estivariz [16] to conclude that the prohormone of this teleost fish is also non-glycosylated. Similarly, biosynthetic studies indicate that the prohormone of the pars intermedia of the lizard, Anolis carolinensis, is not glycosylated [6]. Mammalian POMC in generally found to be glycosylated with the carbohydrate attached in the $\gamma-\mathrm{MSH}$ region of the prohormone. Some mammals, however, have been shown to possess additional glycosylations within their POMC. Biosynthetic studies reveal that the pituitary of the rat and mouse synthesizes two forms of POMC, one form being glycosylated in the $\gamma$-MSH region only, while in the other form of the prohormone there is a glycosylation in the CLIP region as well $[4,5,7,14,21]$. Finally, it has been suggested that porcine POMC possesses two glycosylations within its $\mathrm{NH}_{2}$ - 
terminal region, one of which may be of the O-linked type $[2,24]$.

Processing of POMC in the pars intermedia of the frog yields, besides the various glycopeptides already discussed, a number of non-glycosylated peptides such as des- $\mathrm{N} \alpha-$ acetyl $\alpha$-MSH, CLIP and endorphin-like-peptide [45]. Chromatographic analysis of peptides synthesized from the non-glycosylated prohormone of the tunicamycin-treated tissue reveals that, with the exception of the elution position of $\gamma$-MSH-intermediate (product V), each peptide has an HPLC elution position which corresponds exactly to that of a peptide synthesized by the control tissue leading us to conclude that processing is occurring correctly. The fact that the elution position of the $\gamma$-MSH-intermediate appears to have shifted is to be expected as this peptide is glycosylated in the control tissue and is non-glycosylated in the tunicamycin treated tissue. While a similar shift might have been expected for $\gamma$-MSH (product I), apparently the elution gradient used was inadequate to show this difference; HPLC analysis using a shallower gradient showed that indeed $\gamma$-MSH synthesized by tunicamycin-treated tissue is a more hydrophobic peptide.

We have found, during pulse-chase incubations with frog neurointermediate lobes, that the newly synthesized POMC-related peptides are slowly released [45]. This undoubtly reflects a secretory process as their appearance in the medium is susceptible to regulation by factors known to be involved in the control of melanotropin release in Rana. For example, dopamine inhibits the release of these newly synthesized peptides [20] and the neuropeptide thyrotropin releasing hormone stimulates their release [43]. The HPLC profile of peptides released by the tunicamycin-treated tissue is, with again the exception of the $\gamma$-MSH-intermediate, almost identical to that obtained from the control tissue. This, and the fact that there is very little difference between the two groups in the relative amount of radioactive peptides released, lead us to conclude that lack of glycosylation of POMC has little or no effect on the secretory process.

In Rana, acetylation of des-N $\alpha$-acetyl $\alpha$-MSH to form $\alpha$-MSH (product III) and diacetylated $\alpha$-MSH (product IV) is associated with the release process $[20,44]$, and thus the presence of these peptides is limited to the incubation medium. In the mouse, where acetylation of melanotropins of the pars intermedia is clearly an intracellular event, tunicamycin was found to have a slight inhibitory effect on the acetylation process $[19,21]$.

It is clear from our results that, within the time constraints of our in vitro incubations, tunicamycin treatment has no apparent effect on the acetylation of Rana melanotropin.

Altogether, our results indicate that processing and release of POMC-related peptides is apparently unaffected by tunicamycin treatment. If there is any incorrect cleavage of the non-glycosylated prohormone to give rise to incorrect or "atypical" peptides, then the incidence of this must be too low for the detection limit of our analysis. We therefore conclude that the carbohydrate moiety of frog POMC has no major role in either directing processing of the prohormone or in protecting the prohormone from random proteolysis. Similarly, our data offer no evidence that, in the tunicamycin treated tissue, there is misrouting of proteolytic enzymes to the secretory granules.

In view of the species differences in glycosylation of POMC, discussed earlier, it is perhaps not surprising that we find no important intracellular function for the oligosaccharide side-chain on frog POMC. One might have expected a higher degree of conservation of glycosylation among species if the carbohydrate performed a vital intracellular function. One generalization possible is that POMC of most species is glycosylated in the $\gamma$-MSH region and that both glycosylated $\mathrm{NH}_{2}$-terminal fragments of POMC and glycosylated $\gamma$-MSH are biosynthetic products of the pituitary gland of many species. Interestingly, while $\gamma$-MSH structures are reported to be very weak melanotropins [26], it has been suggested that the $\mathrm{NH}_{2}$-terminal fragment, or $\gamma$-MSH itself, may have a function in regulation of the adrenal gland, not only in mammals $[1,8,9,31,36-38]$ but in submammalian vertebrates as well $[25,42]$. Possibly, the carbohydrate moiety of these peptides could have an extracellular function, such as influencing their biological half-life or play a role in the interaction of these peptides with their target tissue. In this regard it is interesting to note that glycosylated forms of POMC-related peptides have been reported to be less susceptible to proteolysis by trypsin and blood proteases [29].

\section{ACKNOWLEDGEMENTS}

H.V. was a Visiting Professor in the Faculty of Sciences in Nijmegen. We are indebted to Drs. R. Andreatta and K. Scheibli (Ciba-Geigy, Basel, Switzerland) for their kind gift of synthetic $\alpha$-MSH- and ACTH-related peptides and to Dr. N. Ling (The Salk Institute, La Jolla, CA) for his generous gift of $\gamma$-MSH- and $\beta$-endorphin-related peptides. This work was supported by research grants from the Institut National de la Santé et de la Recherche Médicale (82-4019), the Centre National de la Recherche Scientifique (UA 650), the European Economic Community (STI-084JC-CD). We thank Mr. P. M. J. M. Cruijsen for technical assistance and Mrs. I. Culembourg for typing the manuscript.

\section{REFERENCES}

1. Al-Dujaili, E. A. S., B. C. Williams, C. R. W. Edwards, P. Salacinski and P. J. Lowry. Human- $\gamma$-melanotropin precursor potentiates corticotropin-induced adrenal steroidogenesis by stimulating mRNA synthesis. Biochem $J$ 204: 301-305, 1982.

2. Boileau, G., N. Larivière, K. L. Hsi, N. G. Seidah and M. Chrétien. Characterization of multiple forms of porcine anterior pituitary proopiomelanocortin amino-terminal glycopeptide Biochemistry 21: 5341-5346, 1982.

3. Bonner, W. M. and R. A. Laskey. A film detection method for tritium-labelled proteins and nucleic acids in polyacrylamide gels. Eur J Biochem 46: 83-88, 1974.

4. Budarf, M. L. and H. Herbert. Effect of tunicamycin on the synthesis, processing and secretion of pro-opiomelanocortin peptides in mouse pituitary cells. J Biol Chem 257: 10128-10135, 1982.
5. Chrétien, M. and N. G. Seidah. Chemistry and biosynthesis of pro-opiomelanocortin. Mol Cell Biochem 34: 101-127, 1981.

6. Dores, R. M. Evidence for a common precursor for $\alpha-\mathrm{MSH}$ and $\beta$-endorphin in the intermediate lobe of the pituitary of the reptile Anolis carolinensis. Peptides 3: 925-935, 1982.

7. Eipper, B. A. and R. E. Mains. Structure and biosynthesis of pro-adrenocorticotropin/endorphin and related peptides. Endocr Rev 1: 1-27, 1980.

8. Estivariz, F. E., F. Iturriza, C. McLean, J. Hope and P. J. Lowry. Stimulation of adrenal mitogenesis by $\mathrm{N}$-terminal proopiomelanocortin peptides. Nature 297: 419-422, 1982. 
9. Farese, R. V., N. C. Ling, M. A. Sabir, R. E. Larson and W. L. Trudeau. Comparison of effects of adrenocorticotropin and Lys- $\gamma_{3}$-melanocyte stimulating hormone on steroidogenesis, adenosine 3',5'-monophosphate production, and phospholipid metabolism in rat adrenal fasciculata reticularis cells in vitro. Endocrinology 112: 129-132, 1983.

10. Gainer H. Precursor of vasopressin and oxytocin. Prog Brain Res 60: 205-215, 1983

11. Gonzàles, C. B., R. W. Swann and B. T. Pickering. Effect of tunicamycin on the hypothalamo-neurohypophyseal system of the rat. Cell Tissue Res 217: 199-210, 1981.

12. Goos, H. J. Th. and M. Terlou. Hypothalamic control of MSH secretion in lower vertebrates Front Horm Res 4: 51-62, 1977.

13. Hadley, M. E. and V. J. Hruby. Neurohypophyseal peptides and the regulation of melanophore stimulating hormone (MSH) secretion. Am Zool 17: 809-821, 1977.

14. Herbert, E. Discovery of pro-opiomelanocortin, a cellular polyprotein. Trends Biochem Sci 6: 184-188, 1981.

15. Hubbard, S. C. and R. J. Ivatt. Synthesis and processing of asparagine-linked oligosaccharides. Annu Rev Biochem 50: 555-583, 1981.

16. Iturriza, F. C. and F. E. Estivariz. Lack of glycosylation of pro-opiomelanocortin might account for the periodic acid-schiff$\delta$ negative reaction in ACTH-cells of teleost fishes. Gen Comp Endocrinol 61: 229-236, 1986.

17. Jacobs, J. W., P. K. Lund, J. T. Potts, N. H. Bell and J. F. Habener. Procalcitonin is a glycoprotein. $J$ Biol Chem 256: 2803-2807, 1981.

18. Jenks, B. G., J. H. H. N. van Daal, J. G. M. Scharenberg, G. J. M. Martens and A. P. van Overbeeke. Biosynthesis of proopiomelanocortin-derived peptides in the mouse neurointermediate lobe. $J$ Endocrinol 98: 19-34, 1983.

19. Jenks, B. G., P. M. J. M. Cruijsen, J. H. M. Feyen, G. J. M. Martens and A. P. van Overbeeke. Effects of tunicamycin on biosynthesis of pars intermedia peptides in the mouse. In: Neuropeptides and Psychosomatic Processes, edited by E. Endröczi. Budapest: Hungarian Academic Press, 1983, pp. 281-287.

20. Jenks, B. G., B. M. L. Verburg-van Kemenade, M. C. Tonon and $\mathrm{H}$. Vaudry. Regulation of biosynthesis and release of pars intermedia peptides in Rana ridibunda: Dopamine affects both acetylation and release of $\alpha$-MSH. Peptides 6: 913-921, 1985.

21. Jenks, B. G., A. G. H. Ederveen, J. H. M. Feyen and A. P. van Overbeeke. The functional significance of glycosylation of proopiomelanocortin in melanotrophs of the mouse pituitary gland. $J$ Endocrinol 107: 365-374, 1985.

22. Kalyan, N. K. and O. P. Bahl. Role of carbohydrate in human chorionic gonadotropin. J Biol Chem 258: 67-74, 1983.

23. Kawauchi, H. Chemistry of proopiocortin related peptides in the salmon pituitary. Arch Biochem Biophys 227: 343-350, 1983.

24. Larivière, N., N. G. Seidah, G. De Serres, J. Rochemont and M. Chrétien. Two glycosylation sites on the $\mathrm{N}$-terminal segment of procine pars distalis pro-opiomelanocortin. FEBS Lett 122: $279-282,1980$.

25. Leboulenger, F., I. Lihrmann, P. Netchitaïlo, C. Delarue, I. Perroteau, N. Ling and H. Vaudry. In vitro study of frog (Rana ridibunda Pallas) interrenal function by use of a simplified perifusion system. VIII. Structure-activity relationship of synthetic ACTH fragments and $\gamma$-MSH. Gen Comp Endocrinol 61: 187-196, 1986.

26. Ling, N., S. Ying, S. Minick and R. Guillemin. Synthesis and biological activity of four $\gamma$-melanotropin peptides derived from the cryptic region of the adrenocorticotropin/ $\beta$-lipotropin precursor. Life Sci 25: 1773-1780, 1979.

27. Loh, Y. P. and H. Gainer. The role of glycosylation on the biosynthesis, degradation and secretion of ACTH- $\beta$-lipotropin common precursor and its peptide products FEBS Lett 96: $269-272,1978$.
28. Loh, Y. P. and H. Gainer. The role of the carbohydrate in the stabilization, processing, and packaging of the glycosylated adrenocorticotropin-endorphin common precursor in toad pituitaries. Endocrinology 105: 474-487, 1979.

29. Loh, Y. P. and H. Gainer. Evidence that glycosylation of proopiocortin and ACTH influences their proteolysis by trypsin and blood proteases. Mol Cell Endocrinol 20: 35-44, 1980.

30. Loh, Y. P. and H. Gainer. Processing of normal and nonglycosylated forms of toad pro-opiocortin by rat intermediate (pituitary) lobe pro-opiocortin converting enzyme activity. Life Sci 31: 3043-3050, 1982.

31. Lowry, P. J., L. Silas, C. McLean, E. A. Linton and F. E. Estivariz. Pro- $\gamma$-melanocyte-stimulating hormone cleavage in adrenal gland undergoing compensatory growth. Nature 306: 70-73, 1983.

32. McLean, C. and P. J. Lowry. Natural occurrence but lack of melanotrophic activity of $\gamma-\mathrm{MSH}$ in fish. Nature 290: 341-343, 1981.

33. Martens, G. J. M., B. G. Jenks and A. P. van Overbeeke. Biosynthesis of a $\gamma_{3}$-melanotropin-like peptide in the pars intermedia of the amphibian pituitary gland. Eur $J$ Biochem 126: 23-28, 1982.

34. Martens, G. J. M., P. P. J. Biermans, B. G. Jenks and A. P. van Overbeeke. Biosynthesis of two structurally different proopiomelanocortins in the pars intermedia of the amphibian pituitary gland. Eur J Biochem 126: 17-22, 1982.

35. North, W. G., H. Valtin, S. Cheng and G. R. Hardy. The neurophysins: production and turnover. Prog Brain Res 60: $217-225,1983$

36. Pedersen, R. C. and A. C. Brownie. Adrenocortical response to corticotropin is potentiated by part of the amino-terminal region of pro-corticotropin/endorphin. Proc Natl Acad Sci USA 77: 2239-2243, 1980.

37. Pedersen, R. C., A. C. Brownie and N. Ling. Pro-adrenocorticotropin/endorphin-derived peptides: coordinate action on adrenal steroidogenesis Science 208: 1044-1046, 1980.

38. Pedersen, R. C. and A. C. Brownie. Lys- $\gamma_{3}$-melanotropin binds with high affinity to the rat adrenal cortex. Endocrinology 112: 1279-1287, 1983

39. Richter, D. and H. Schmale. The structure of the precursor to arginine vasopressin: a model prohormone. Prog Brain Res 60: 227-233, 1983.

40. Schwarz, R. T. and R. Datema. Inhibitors of protein glycosylation. Trends Biochem Sci 5: 65-67, 1980.

41. Shimohigashi, Y. and H. C. Chen. Carbohydrate structures in the $\beta$-subunit of human chorionic gonadotropin play a dominant role in hormonal activation. FEBS Lett 150: 64-68, 1982.

42. Takahashi, A., J. Kubota, H. Kawauchi and T. Hirano. Effects of $\mathrm{N}$-terminal peptide of salmon proopiocortin on interrenal function of the rainbow trout. Gen Comp Endocrinol 58: 328335,1985

43. Tonon, M. C., P. Leroux, B. G. Jenks, L. Gouteux, S. Jégou, J. Guy, G. Pelletier and H. Vaudry. The intermediate lobe of the amphibian pituitary: an endocrine gland which gives rise to multiple hormonal peptides is regulated by multiple control mechanisms. Ann Endocrinol (Paris) 46: 69-87, 1985.

44. Vaudry, H., B. G. Jenks and A. P. van Overbeeke. The frog pars intermedia contains only the non-acetylated form of $\alpha$-MSH: acetylation to generate $\alpha$-MSH occurs during the release process. Life Sci 33: 97-100, 1983.

45. Vaudry, H., B. G. Jenks and A. P. van Overbeeke. Biosynthesis, processing, and release of pro-opiomelanocortin related peptides in the intermediate lobe of the pituitary gland of the frog (Rana ridibunda). Peptides 5: 905-912, 1984 